\title{
Climatic controls on diffuse groundwater recharge across Australia
}

\author{
O. V. Barron ${ }^{1}$, R. S. Crosbie ${ }^{2}$, W. R. Dawes ${ }^{1}$, S. P. Charles ${ }^{1}$, T. Pickett ${ }^{3}$, and M. J. Donn ${ }^{1}$ \\ ${ }^{1}$ CSIRO Land and Water, Private Bag 5, Wembley, Western Australia 6913, Australia \\ ${ }^{2}$ CSIRO Land and Water, Gate 4 Waite Road, Urrbrae, South Australia 5064, Australia \\ ${ }^{3}$ CSIRO Land and Water, Ecosciences Precinct, 41 Boggo Road, Dutton Park, Queensland 4102, Australia \\ Correspondence to: O. V. Barron (olga.barron@csiro.au)
}

Received: 1 March 2012 - Published in Hydrol. Earth Syst. Sci. Discuss.: 9 May 2012

Revised: 19 October 2012 - Accepted: 26 October 2012 - Published: 4 December 2012

\begin{abstract}
Reviews of field studies of groundwater recharge have attempted to investigate how climate characteristics control recharge, but due to a lack of data have not been able to draw any strong conclusions beyond that rainfall is the major determinant. This study has used numerical modelling for a range of Köppen-Geiger climate types (tropical, arid and temperate) to investigate the effect of climate variables on recharge for different soil and vegetation types. For the majority of climate types, the correlation between the modelled recharge and total annual rainfall is weaker than the correlation between recharge and the annual rainfall parameters reflecting rainfall intensity. Under similar soil and vegetation conditions for the same annual rainfall, annual recharge in regions with winter-dominated rainfall is greater than in regions with summer-dominated rainfall. The importance of climate parameters other than rainfall in recharge estimation is highest in the tropical climate type. Mean annual values of solar radiation and vapour pressure deficit show a greater importance in recharge estimation than mean annual values of the daily mean temperature. Climate parameters have the lowest relative importance in recharge estimation in the arid climate type (with cold winters) and the temperate climate type. For $75 \%$ of all soil, vegetation and climate types investigated, recharge elasticity varies between 2 and 4 indicating a $20 \%$ to $40 \%$ change in recharge for a $10 \%$ change in annual rainfall. Understanding how climate controls recharge under the observed historical climate allows more informed choices of analogue sites if they are to be used for climate change impact assessments.
\end{abstract}

\section{Introduction}

Diffuse groundwater recharge, as recharge related to rainfall percolation across the landscape (and opposite to localised recharge, associated with water leakage from surface water features, e.g. rivers or lakes), is strongly influenced by local vegetation and climate characteristics, which are largely dependant on the climate types. The major climate types, as classified based on the Köppen-Geiger method (Peel et al., 2007), are tropical (A), arid (B), temperate (C), cold (D) and polar (E) with further sub-division based on annual and seasonal rainfall and temperature distribution. Based on such a broad classification, the relationships between groundwater recharge and climate characteristics under these climate types are significantly different. This is due to variation in precipitation, its type (snow or rain), seasonality and intensity and also the effect of vegetation on groundwater recharge. The latter can influence seasonal and annual water use by plants within various climatic conditions and therefore the proportion of rainfall which becomes recharge.

A recent review of field-based recharge estimates in Australia investigated the influence of Köppen-Geiger climate types on the relationship between rainfall and recharge (Crosbie et al., 2010a). That study found that there were some differences between recharge under winter-dominated rainfall when compared to equi-seasonal rainfall, but the results were confounded by differing soil types and so no strong conclusions could be drawn. It was also found that temperature distinctions within the Köppen-Geiger climate types were not correlated with recharge.

Considering the difficulties in designing a field-based experiment to investigate the controls that climate characteristics have on recharge, modelling is the favoured method 
for investigation. Climate change impact studies have provided some information on climatic controls on recharge but generally consider only regions that have a limited range of climate types. It has been shown that, in general, rainfall is the most important climate parameter influencing recharge (Allen et al., 2004; Serrat-Capdevila et al., 2007). However, many exceptions have been reported (Crosbie et al., 2010b; Döll, 2009; Rosenberg et al., 1999) which indicates that other factors can influence this relationship. Among them are the frequency and seasonality of rainfall. Vivoni et al. (2009) demonstrated for a catchment in New Mexico that either an increase in the intensity of summer rainfall or an increase in the frequency of winter rainfall can lead to an increase in recharge. In semi-arid areas, higher intensity rainfall can lead to higher episodic recharge even under projections of decreased total rainfall (Crosbie et al., 2012a; Ng et al., 2010).

Most studies that have reported an influence of temperature upon recharge have been for cold climates, and are associated with variations in snowfall, snowmelt and frozen ground under different temperature conditions (Eckhardt and Ulbrich, 2003; Jyrkama and Sykes, 2007; Okkonen et al., 2010; Vivoni et al., 2009). For warmer climates with a waterlimited environment, Rosenberg et al. (1999) found that recharge could decrease with an increase in rainfall due to higher temperatures and higher evapotranspiration rates in the Ogallala Aquifer. In the Upper Nile Basin, it was found that a $3{ }^{\circ} \mathrm{C}$ increase in temperature along with an increase in rainfall led to a reduction in recharge. This was attributed to the effect of higher temperature on evapotranspiration (Kingston and Taylor, 2010).

Furthermore, recharge can be influenced by variability in solar radiation, vapour pressure deficit and $\mathrm{CO}_{2}$ concentration as these climate characteristics influence the vegetation water demands and water use efficiency (McCallum et al., 2010). Natural vegetation is largely adapted to local climatic conditions, and some titles of climate types reflect this (e.g. tundra or steppe or savannah). Changes in climatic conditions, which lead to changes in the vegetation and/or their water use efficiency, can have a follow-on impact on recharge. For instance, increased recharge was simulated in parts of the Murray-Darling Basin despite a decrease in rainfall, and this was attributed to a reduction in transpiration; i.e. the transpiration reduced due to the effect of temperature on vegetation when the optimum temperature for vegetation growth was exceeded (Crosbie et al., 2010b).

Understanding of the effect of climate types on recharge as a renewable groundwater resource is particularly important in larger countries (such as Australia, USA, China or Russia) or regions where groundwater management is set to be undertaken by a group of the countries (such as the European Union) where the managed area extends across a number of climate types. As climate change is a growing concern in water management globally, knowledge of the processes influencing water resources in individual climate zones and also their potential changes are important for development of an adequate climate change adaptation strategy and adequate fresh groundwater resources management.

In addition, the effect of climate change is likely to vary in different climate types (IPCC, 2007), so the consequent impact on groundwater resources is likely to be specific in the region of their occurrence. In addition, the projected changes in temperature and rainfall may lead to a climate type shift, causing further changes in land cover or land use (Crosbie et al., 2012c). This may further impact groundwater resources.

Australia has a contrasting and highly variable climate, with large regions experiencing arid and semi-arid climates. This has resulted in increasing pressures on groundwater resources as the population has grown and development has taken place (DEWHA, 2010). The reduction in rainfall in many Australian regions (particularly southern regions) over recent years has seen both a reduction in recharge and an increase in groundwater use as surface water resources have become scarce (CSIRO, 2008, 2009a, b, c). Limited water resource availability already constrains regional development in many parts of Australia. Understanding how climate characteristics control recharge under the observed historical climate is the key to making projections of how recharge will change under a future climate.

Using recharge estimates from a numerical model, this paper aims to investigate the control that climate characteristics have over groundwater recharge at a point scale with an analysis of the results aggregated to the climate zone scale and ultimately a continental scale. Specifically it will

- examine the influence of rainfall, including total rainfall, rainfall intensity and rainfall seasonality, on recharge as these climate parameters are considered to be the most influential in recharge estimation (Crosbie et al., 2010a; Owor et al., 2009; and Petheram et al., 2002);

- examine the influence of other climate variables, such as vapour pressure deficit, temperature and solar radiation, on recharge as these parameters affect evapotranspiration and therefore indirectly the amount of rainfall which becomes recharge (Monteith, 1967);

- make recommendations for climate change impact studies.

In the following discussion the term "climate type" will be used when the climate characteristics are discussed, while the term "climate zone" will be used when the geographical extent of a climate type occurrence is referred to.

\section{Climate types in Australia}

There are 15 Köppen-Geiger climate types in Australia, shown in Fig. 1. However the largest areas of the continent are associated with 8 climate types summarized in Table 1: 


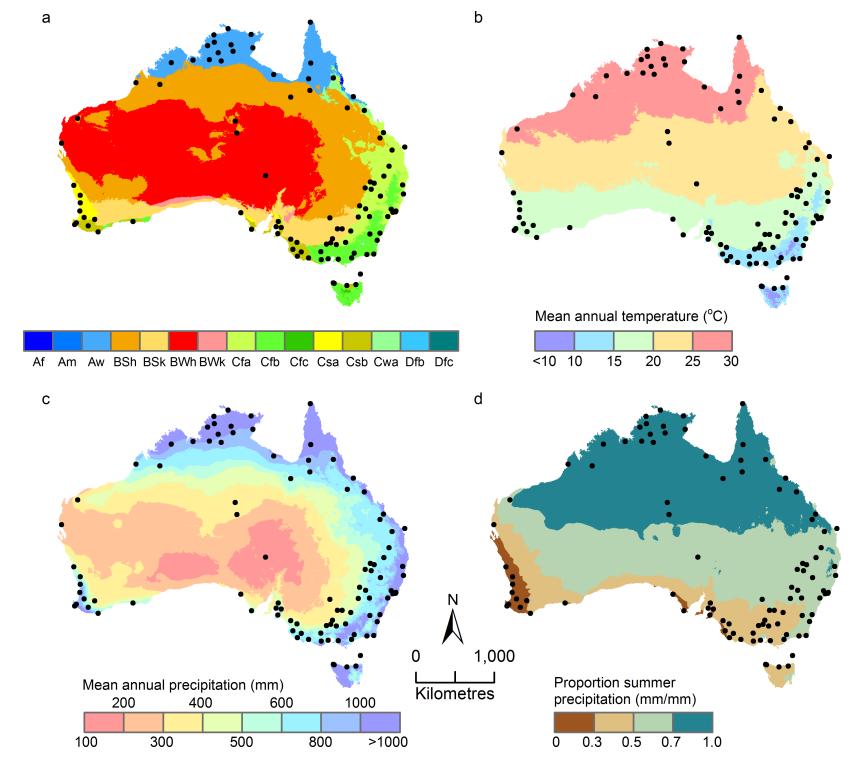

Fig. 1. Climate parameters (as mean over the period 1930-2010): (a) Köppen-Geiger climate zones; (b) annual temperature; (c) annual precipitation; (d) proportion of summer precipitation in annual mean rainfall; the points indicate the location where climate data was obtained for recharge modelling. Adapted from Barron et al. (2011); climate types Af, Am, Cfc, Cwa, Dfb and Dfc have limited spatial distribution and combined they cover less than $1 \%$ of the continent.

tropical savannah (Aw), three arid types (BWh, BSh and $\mathrm{BSk}$ ) and four temperate types ( $\mathrm{Cfa}, \mathrm{Cfb}, \mathrm{Csa}$ and $\mathrm{Csb}$ ).

Climate types are closely linked to rainfall distribution, rainfall intensity and seasonality across the continent (BoM, 2011a). The northern regions (under climate type Aw and partly the northern part of arid BSh zone; see Table 1) are greatly influenced by monsoons and tropical cyclones, both of which bring heavy rains during the summer months. Rainfall in the south-west (Csa/Csb climate types) is dominated by heavy rain events occurring during winter. In the south and south-east, frontal weather systems and east coast lows during winter, in combination with localised troughs, bring occasional heavy rains with prolonged periods of lower intensity rainfall, mainly during winter. The sub-tropical ridge brings dry and stable conditions to large parts of middle Australia. To some extent, the approximate position of the ridge separates the summer-dominated rainfall in the north from the winter-dominated rainfall in the south. The southern regions also experience an overall cooler climate.

General characterization of the main climate types in Table 1 shows a large range of mean annual rainfall within each climate zone, and the maximum values of mean annual rainfall can be seven times the minimum value of mean annual rainfall such as under temperate $\mathrm{Cf}$ climates. The lowest range in mean annual rainfall is in arid BSk climate. The range of mean temperatures across individual climate zones could be greater than $10^{\circ} \mathrm{C}$ as under temperate $\mathrm{Cfb}$ climate and also arid BWh and BSh climates, which have a large longitudinal and latitudinal extent. The lowest range in mean temperatures is in arid BSk climate which are less than $4^{\circ} \mathrm{C}$.

\section{Methods}

The method of investigation of the effect of climate characteristics and their combination within individual climate types on diffuse recharge in Australia was based on a statistical analysis of the climate data and corresponding modelled recharge data for the regions with the main climate types.

\subsection{Recharge modelling}

Groundwater recharge was modelled using a slightly modified version (McCallum et al., 2010) of the unsaturated zone model WAVES (Zhang and Dawes, 1998). WAVES is a soilvegetation-atmosphere-transfer model that achieves a balance in its modelling complexity between carbon, energy and water balances (Zhang and Dawes, 1998). Its ability to simulate plant physiology allows changes in temperature and $\mathrm{CO}_{2}$ to show impacts on transpiration, and therefore recharge. Using the Penman-Monteith equation (Penman, 1967) for the energy balance allows the evapotranspiration to be controlled by the dynamic vegetation growth responding to the availability of water, nutrients and light (Wu et al., 1994). The modelling of the unsaturated zone using Richards equation allows water movement to be modelled under dry conditions (Scanlon et al., 2002). WAVES has been shown to be able to reproduce the water balance of field experiments in many studies around Australia (Crosbie et al., 2008; Dawes et al., 2002; Salama et al., 1999; Slavich et al., 1999; Xu et al., 2008; Zhang et al., 1999) and throughout the world (Wang et al., 2001; Yang et al., 2003; Zhang et al., 1996). WAVES has been shown to perform similarly to three other hydrological models in a comparison study of the climate change impacts on recharge (Crosbie et al., 2011a). As has previously been done (Crosbie et al., 2010b, 2012b), drainage below the bottom of a 4-m soil column is assumed to become groundwater recharge; this is to be considered potential dryland diffuse recharge as other forms of recharge (e.g. focused recharge or irrigation drainage) are not considered in this paper.

Soil data, including hydraulic characteristics, were derived from the ASRIS v1 database (Johnston et al., 2003). The soil profile was modelled as a two-layer system, with $0.5 \mathrm{~m}$ topsoil and $3.5 \mathrm{~m}$ subsoil with topsoil typically being more permeable than subsoil. A soil column of $4 \mathrm{~m}$ was chosen to be deep enough that rooting depth of the vegetation can be varied between perennials and annuals but not so deep as to be unrepresentative of large parts of the study area.

The recharge modelling was undertaken for three vegetation classes: annuals, perennials and trees. These three classes of vegetation have traditionally been used in classifying vegetation for field-based recharge studies (Crosbie 
Table 1. Characteristics of selected climate zones.

\begin{tabular}{|c|c|c|c|c|c|c|c|}
\hline \multirow[b]{2}{*}{ Climate types } & & \multicolumn{2}{|c|}{ Rainfall } & \multicolumn{2}{|c|}{$\begin{array}{l}\text { Rainfall seasonality: } \\
\text { summer rainfall as } \\
\text { proportion of annual }\end{array}$} & \multicolumn{2}{|c|}{ Mean temperature } \\
\hline & & Annual $^{\mathrm{a}}(\mathrm{mm})$ & Range $^{\mathrm{b}}(\mathrm{mm})$ & Annual $^{\mathrm{a}}$ & Range $^{b}$ & Annual ${ }^{\mathrm{a}}\left({ }^{\circ} \mathrm{C}\right)$ & Range $^{\mathrm{b}}\left({ }^{\circ} \mathrm{C}\right)$ \\
\hline Tropical savannah & Aw & 1125 & $758-2038$ & 0.92 & $0.67-0.96$ & 26.7 & $22.3-29.5$ \\
\hline Arid desert hot & BWh & 254 & $138-417$ & 0.67 & $0.26-0.88$ & 22.5 & $18.0-28.2$ \\
\hline Arid steppe hot & BSh & 483 & $225-870$ & 0.75 & $0.15-0.96$ & 23.4 & $18.0-29.7$ \\
\hline Arid steppe cold & BSk & 342 & $235-498$ & 0.44 & $0.26-0.69$ & 16.9 & $14.2-18.0$ \\
\hline $\begin{array}{l}\text { Temperate without } \\
\text { dry season with } \\
\text { hot summer }\end{array}$ & $\mathrm{Cfa}$ & 762 & $439-3493$ & 0.63 & $0.37-0.79$ & 18.6 & $14.1-23.4$ \\
\hline $\begin{array}{l}\text { Temperate without } \\
\text { dry season with } \\
\text { warm summer }\end{array}$ & $\mathrm{Cfb}$ & 953 & 433-3219 & 0.49 & $0.33-0.72$ & 12.8 & $6.7-18.5$ \\
\hline $\begin{array}{l}\text { Temperate with } \\
\text { dry hot summer }\end{array}$ & Csa & 557 & $341-1517$ & 0.22 & $0.15-0.77$ & 17.5 & $14.8-21.5$ \\
\hline $\begin{array}{l}\text { Temperate with } \\
\text { dry warm summer }\end{array}$ & $\mathrm{Csb}$ & 665 & $347-1200$ & 0.30 & $0.15-0.40$ & 15.0 & $9.3-17.3$ \\
\hline
\end{tabular}

${ }^{a}$ Mean value across the climate zone, estimated using mean annual values of the relevant parameter within each climate zone. ${ }^{b}$ The range of mean annual values within each climate zone.

et al., 2010a; Petheram et al., 2002), and this has been carried forward into modelling studies (Crosbie et al., 2010b, 2012b). Annuals are mainly shallow rooted crops and pasture; there is no ground cover for part of the year so recharge is highest under this vegetation type. Perennials are generally grasslands where there is groundcover year round; recharge is lower than annuals but higher than the deep rooted tree vegetation. The vegetation parameters required by WAVES were taken from the user manual (Dawes et al., 2004). The annuals (including crops) were modelled as annual pasture; the perennials were modelled as perennial pasture and the trees (including forestry) as an overstorey of eucalypts with an understorey of perennial grasses. Each climate zone used different parameters for each of the three vegetation types modelled to account for different species present in each climate zone (Crosbie et al., 2012b).

It was observed that the modelled recharge across the continent showed a similar trend in the relationship between soil permeability and recharge. As illustrated in Fig. 2, the range of the estimated recharge is the greatest for soils with hydraulic conductivity less than $1 \mathrm{~m} \mathrm{~d}^{-1}$, expressed as a weighted mean of the topsoil and subsoil hydraulic conductivity $(K)$. For all considered combination of soils and vegetation types, the estimated recharge remained nearly constant for soils with $\mathrm{K}$ greater than $1.5 \mathrm{~m} \mathrm{~d}^{-1}$. For this reason, and despite a large variety of soils modelled, the results are presented only for three soil types with low, medium and high hydraulic conductivity, approximately defined as $0.01,0.1$ and $1.0 \mathrm{~m} \mathrm{~d}^{-1}$ respectively. This allowed a better comparison of recharge for different climate types.
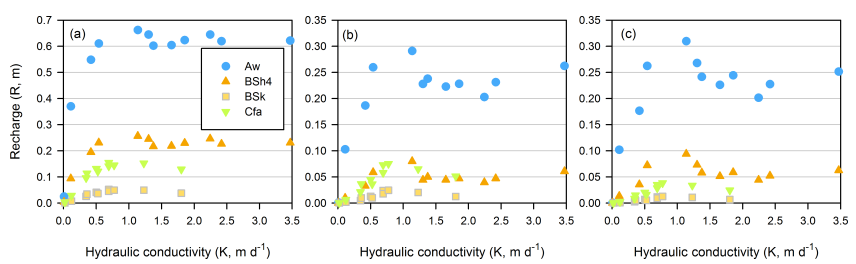

Fig. 2. Modelled annual recharge $(R)$ under soils with various hydraulic conductivity (soil hydraulic conductivity is estimated as $K=\frac{k_{t} m_{t}+k_{s} m_{s}}{m_{t}+m_{s}}$, where $k_{i}$ and $m_{i}$ are hydraulic conductivity and thickness of topsoil $(t)$ and subsoil $(s)$ ) for three types of land cover: (a) annuals, (b) perennials and (c) trees.

The climate data that WAVES requires are rainfall, maximum temperature, minimum temperature, vapour pressure deficit and solar radiation supplied to the model at a daily time step. The historical climate data were extracted from SILO (Jeffrey et al., 2001), an enhanced climate database hosted by the Queensland Climate Change Centre of Excellence, for the 80-yr period from 1930 to 2009. This period was chosen as it was reported to be the most reliable for climate impact assessments in many regions of Australia (CSIRO, 2008, 2009a, b). The recharge modelling was undertaken using observed climate data at 100 locations across Australia, selected to reflect the rainfall gradient within individual climate zones. Their positions were biased toward areas where groundwater is used from unconfined aquifers.

The points used for modelling recharge in the current study were chosen to represent different climate zones rather than where detailed field estimates of recharge have been undertaken. WAVES has been demonstrated to be capable of 
reproducing field observations at a point scale (Crosbie et al., 2008; Dawes et al., 2002; Salama et al., 1999; Slavich et al., 1999; Xu et al., 2008; Zhang et al., 1999) as well as being capable of representing the trends in recharge under different soil and vegetation combinations at a regional scale (Crosbie et al., 2010a, 2011b). As we are confident that WAVES is correctly simulating the process of recharge but do not have the data available to verify the magnitude of the recharge, the results will mainly be reported in relative terms.

\subsection{Climate parameters and diffuse groundwater recharge}

A set of analyses were undertaken to investigate the effect of historical climate characteristics on modelled recharge and to define the importance of annual rainfall, temperature, solar radiation and vapour pressure deficit (VPD) in recharge estimation. In addition the sensitivity of changes in recharge to a change in rainfall (recharge elasticity) was examined as well as the rainfall parameters which better define the effect of rainfall intensity on recharge.

\subsubsection{Time-series data preparation}

The daily series of modelled recharge were aggregated to an annual time series, with the start date being dependent on rainfall seasonality. In areas that experienced summerdominated rainfall, the aggregation period began in September; otherwise the aggregation period began in March. The Köppen-Geiger climate type was calculated for each of the 100 points using the definitions of Peel et al. (2007).

Rainfall and recharge were aggregated by summation, while other climate variables were averaged. Additional methods for categorising rainfall were also used to investigate the effect of rainfall intensity, and these involved summation of rainfall events that were

- above a threshold value $(5 \mathrm{~mm}, 10 \mathrm{~mm}, 20 \mathrm{~mm}, 40 \mathrm{~mm}$, $60 \mathrm{~mm}$ );

- within a range $(0-20 \mathrm{~mm}, 20-40 \mathrm{~mm}, 40-60 \mathrm{~mm})$;

- larger than the 95th or 99th percentile rainfall event;

- above a threshold using a moving-average approach.

The moving-average approach was applied to account for the effect of a prolonged rainfall period on recharge. This involved calculating the moving average of the daily rainfall series applying a 7, 14, and 21 day window, and then summing the averaged rainfall values that were above a threshold of $2.5 \mathrm{~mm} \mathrm{~d}^{-1}$ or $5 \mathrm{~mm} \mathrm{~d}^{-1}$ (Table 2).

The measure used to quantify the effect of climate variables on recharge was Pearson's product moment correlation coefficient, which defines the relative importance (RI) of climate variables in their contribution to explaining variance in recharge (Gromping, 2006). "Relative importance" refers to
Table 2. The minimum daily rainfall event fully accounted in moving-average analysis over the set of considered periods and daily thresholds.

\begin{tabular}{|c|c|c|}
\hline \multicolumn{2}{|c|}{$\begin{array}{l}\text { Moving average period } \\
\text { and threshold }\left(\mathrm{mm} \mathrm{day}^{-1}\right)\end{array}$} & $\begin{array}{r}\text { Daily rain as a single } \\
\text { event over the defined } \\
\text { period }(\mathrm{mm})\end{array}$ \\
\hline \multirow[t]{2}{*}{7 days } & 2.5 & 17.5 \\
\hline & 5.0 & 35 \\
\hline \multirow[t]{2}{*}{14 days } & 2.5 & 35 \\
\hline & 5.0 & 70 \\
\hline \multirow[t]{2}{*}{21 days } & 2.5 & 52.5 \\
\hline & 5.0 & 105 \\
\hline
\end{tabular}

the quantification of an individual regressor's contribution to a multiple regression model. Each regressor's contribution is the $r^{2}$ from univariate regression, and all univariate $r^{2}$-values add up to the full model $r^{2}$. The relative importance measure used in this case was based on the approach proposed by Lindeman et al. (1980), as recommended by Gromping (2006).

\subsubsection{Recharge elasticity}

Similar to the concept of the runoff elasticity to precipitation $(P)$, the relationship of elasticity of recharge $(R)$ to $P$ can be estimated as (after Schaake, 1990)

$\varepsilon(P, R)=\frac{\mathrm{d} R}{\mathrm{~d} P} \frac{P}{R}$.

The modelled recharge data and observed rainfall data were used for recharge elasticity analysis. Similar analysis has been done for surface runoff elasticity estimation (Chiew, 2006), but is not commonly considered for groundwater recharge characterization.

\section{Results}

The modelling results indicate that the recharge values within the same climate type can vary by more than 25 -fold due to changes in land cover (i.e. vegetation) and more than 400fold under various soils. At the same time, a proportion of annual rainfall that becomes recharge can vary from less than one percent under trees and low permeability soils to more than 50 percent under annuals and highly permeable soils.

In addition to soil and vegetation influence, the climate types in Australia have an effect on the relationship between rainfall and recharge. To allow a comparative analysis of the climate type effect on recharge, nine combinations of soils and land cover are presented in following sections, including three soil permeability types (low $K=0.01 \mathrm{~m} \mathrm{~d}^{-1}$, medium $K=0.1 \mathrm{~m} \mathrm{~d}^{-1}$ and high $K=1 \mathrm{~m} \mathrm{~d}^{-1}$ ) with land covers of annual crops, perennial vegetation and trees. 


\subsection{Relative importance of climate characteristics in recharge estimation}

For most analysed data, rainfall $(P)$ had a higher relative importance $\left(\mathrm{RI}^{P}\right)$ in recharge estimation than the other climate variables, including mean annual temperature $(T)$, vapour pressure deficit (VPD) and solar radiation (SR) $\left(\sum \mathrm{RI}^{\mathrm{SR}, \mathrm{VDP}, T}\right)$. Figure 3 shows the combined relative importance $\left(\sum R \mathrm{R}\right)$ of the four climate variables for selected soils and land cover averaged for all climate types. $\sum R \mathrm{RI}$ indicates that the degree of inter-annual recharge variability explained by variability in the climate characteristics and $\sum \mathrm{RI}$ varies from more than $95 \%$ (or 0.95 in Fig. 3) to less than $30 \%$ (or 0.3 in Fig. 3). In all climate types the relative importance of annual climate characteristics in recharge estimation reduces from annual to perennial vegetation to trees. It is also low under the least permeable soils. The lower $\sum \mathrm{RI}$ indicates that other variables, which are not incorporated into the considered annual mean values, have a greater impact on recharge in such conditions.

The only climate type where RI of rainfall is lower than $\sum \mathrm{RI}^{\mathrm{SR}, \mathrm{VDP}, T}$ is the arid (BSk) climate under low permeable soils and perennial vegetation or trees. Under this climate type, $\sum \mathrm{RI}$ values in recharge estimation are the overall lowest across all other climate types (Fig. 3).

The highest values of $\sum \mathrm{RI}^{\mathrm{SR}, \mathrm{VDP}, T}$ are related to (i) the climates with summer-dominated rainfall (Aw and Cfa) and (ii) the cooler climate types ( $\mathrm{Cfb}$ and $\mathrm{Csb}$ ) where the ranges of the solar radiation and temperature are greater and their mean values are lower than in other climate types.

Compared to VPD and solar radiation, mean annual temperature has the lowest relative importance under all climate types, which is likely to be due to a relative consistency of mean annual temperature within individual climate type over the simulation period (BoM, 2011b). However the high $\sum \mathrm{RI}^{T}$-values are related to a cooler climate $(\mathrm{Cfb})$, climate with winter-dominated rainfall (Csa) and arid climate (BSh), which covers the large area with a greatest variability in annual temperature (Fig. 1b). On average, climate variables other than rainfall explain $15 \%$ of the variability of recharge, with a maximum of $30 \%$.

When individual points within each climate type are considered (Fig. 4), the rainfall importance in recharge estimation reduces under lower annual rainfall conditions within each individual climate type and also across the entire data set. For the latter, $\mathrm{RI}^{P}$ was found to be lowest for areas with annual rainfall less than $700 \mathrm{~mm}$. In agreement with the discussion above, the relative importance of rainfall under all soil/vegetation is the lowest under the arid climate BSk, and also in the areas neighbouring with the BSk climate zone. This includes the western areas of the temperate climate zones $(\mathrm{Cf})$ and the southern areas of the BSh arid climate zone. When annual rainfall is lower than $400 \mathrm{~mm}$, it appears that the relative importance of rainfall increases, e.g. desert climate type (BWh).
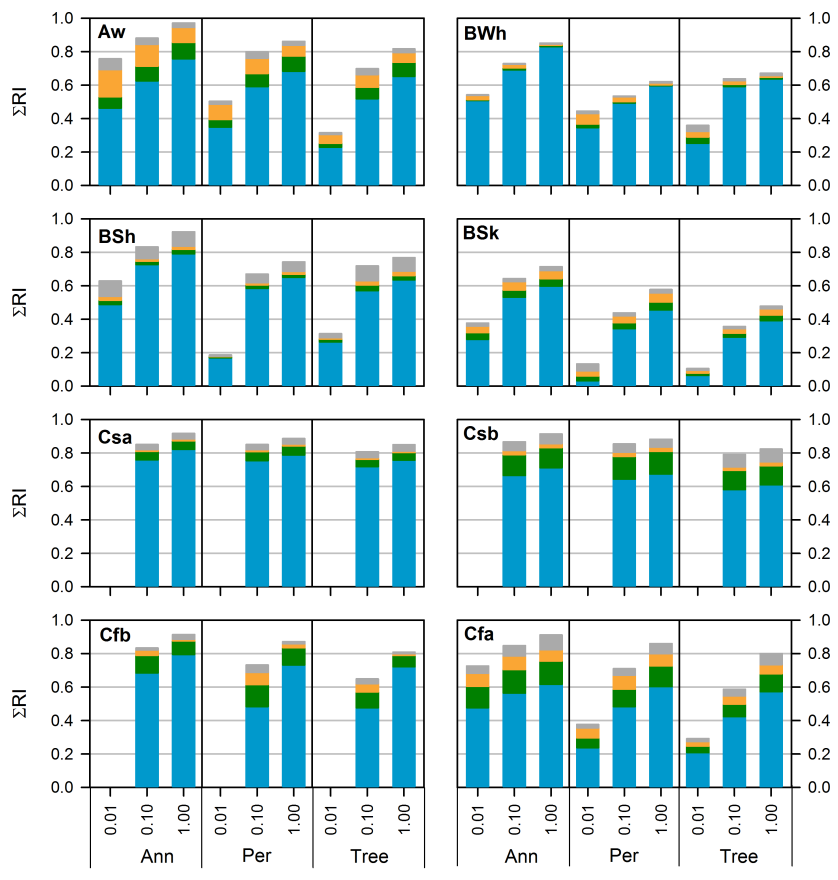

Soil hydraulic conductivity $(K)$ and vegetation type

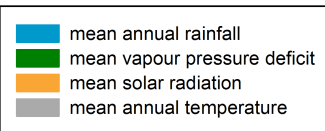

Fig. 3. Relative importance of climate characteristics $\left(\sum \mathrm{RI}\right)$ for the considered climate types (see Fig. 1), under soil with selected hydraulic conductivities $\left(K=0.01 \mathrm{~m} \mathrm{~d}^{-1}, 0.1 \mathrm{~m} \mathrm{~d}^{-1}\right.$ or $\left.1.0 \mathrm{~m} \mathrm{~d}^{-1}\right)$ and three vegetation types (Ann - annuals, Per - perennials and Trees); note that in Csa, Csb and $\mathrm{Cfb}$ zones, clay-rich soils ( $K=$ $0.01 \mathrm{~m} \mathrm{~d}^{-1}$ ) are not present.

Within individual climate types, $\mathrm{RI}^{P}$ changes are related to the distribution of annual mean rainfall within the zone and are influenced by the other climate types located in the neighbouring regions. For instance, temperate climate Cfa covers the eastern regions of the country stretching from the northeast to south-east. It is characterised by the greatest variation in rainfall and its relative importance in recharge estimation. The higher $\mathrm{RI}^{P}$-values are related to the most northern modelled points that are similar to $\mathrm{RI}^{P}$ in tropical climate (Aw), while the lowest $\mathrm{RI}^{P}$-values are found for the most southern modelled points that are similar to $\mathrm{RI}^{P}$ under arid climate (BSk) (Fig. 4). Another example is related to $\mathrm{RI}^{P}$ variability within the arid climate $\mathrm{BSh}$, which is also greatly influenced by the position of this climate zone in relation to other climate zones. When neighbouring with tropical climate (Aw), $\mathrm{RI}^{P}$ has the higher values; when neighbouring with other arid climates (BSh) $-\mathrm{RI}^{P}$ has the lowest values.

The variability in $\mathrm{RI}^{P}$, indicated by a spread of points in Fig. 4, increases from more to less permeable soil (note that heavier soils with $K=0.01 \mathrm{~m} \mathrm{~d}^{-1}$ are not present in $\mathrm{Cfb}$ and $\mathrm{Csa} / \mathrm{b}$ climate zones). For all soil types the annual rainfall, 


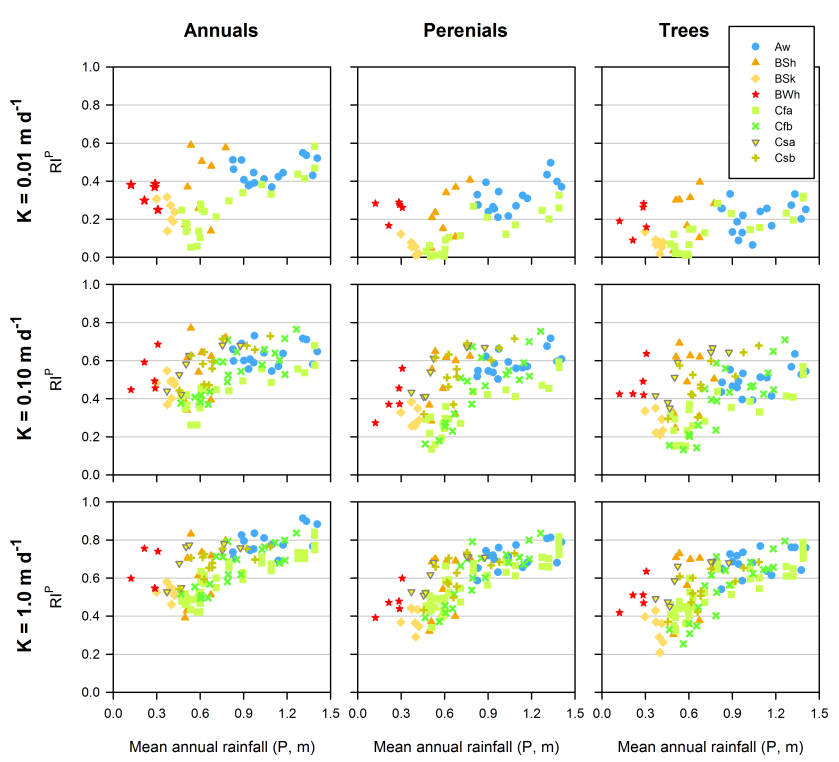

Fig. 4. Scatter plots of mean annual rainfall $(P)$ and its relative importance $\left(\mathrm{RI}^{p}\right)$ in recharge estimation within considered climate types, under soil with selected hydraulic conductivities and vegetation types.

which corresponds to the minimum $\mathrm{RI}^{P}$, is lower under tree land cover, which is about $400 \mathrm{~mm}$ against $500 \mathrm{~mm}$ under annuals. Under the same annual rainfall, $\mathrm{RI}^{P}$ in recharge estimation is greater for temperate climate types with winterdominated rainfall $(\mathrm{Cs})$.

The reduction in annual rainfall and its relative importance leads to an increase in recharge sensitivity to other climate parameters considered in this study (Fig. 5). Under similar annual rainfall $\sum \mathrm{RI}^{\mathrm{SR}, \mathrm{VDP}, T}$ is greater for the climate types with summer-dominated rainfall or cooler climate.

As rainfall is the major factor in recharge, the following Sects. 4.2 and 4.3 examine the relationship between rainfall and recharge only.

\subsection{Relationship between annual rainfall and modelled recharge}

Reflecting the high importance of rainfall in recharge estimation, the correlation between observed rainfall and modelled recharge is strong for the majority of cases and the coefficient of correlation $\left(r_{P}^{2}\right)$ is greater than 0.7 (as recommended by Håkanson and Peters, 1995) for $82 \%$ cases of soil/vegetation/climate type combinations. The strongest correlation between annual recharge and annual rainfall is in the areas with high annual rainfall under tropical savannah (Aw), and temporal climate types without dry season (Cf) (Fig. 6). Correlation between rainfall and recharge becomes weaker under climate types with overall lower annual rainfall as its importance in recharge estimation also drops for rainfall below $700 \mathrm{~mm}$ (Fig. 4). As a result arid climate types,

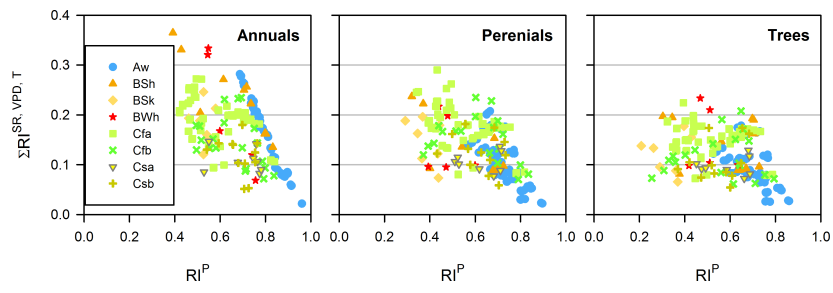

Fig. 5. Scatter plots of relative importance of rainfall $\left(\mathrm{RI}^{p}\right)$ and the sum of relative importance of $T$, VPD and solar radiation $\left(\mathrm{RI}{ }^{\mathrm{SR}}, \mathrm{VPD}, T\right)$ within considered climate types for three vegetation types and soil with hydraulic conductivity $K=1.0 \mathrm{~m} \mathrm{~d}^{-1}$.

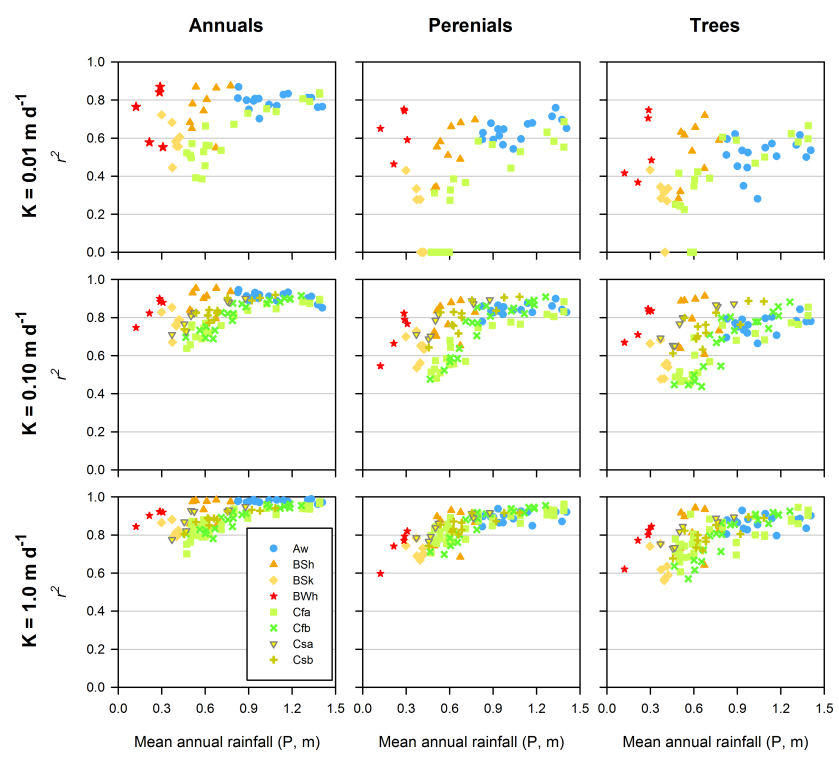

Fig. 6. Scatter plots of mean annual rainfall $(P)$ and the coefficient of correlation $\left(r^{2}\right)$ between mean annual recharge $(R)$ and mean annual $P$ for all modelled locations within considered climate types, under soil with selected hydraulic conductivities and vegetation types.

particularly BSk, are characterized by the overall weakest relationship between rainfall and recharge.

Correlation between rainfall and recharge is generally weaker under perennial vegetation and trees and under soil with lower permeability, where recharge is relatively low. Under similar annual rainfall, $r_{P}^{2}$ is greater in the climate types with winter-dominated rainfall (Cs) for all combinations of vegetation and soil, occurring within these regions.

The stronger correlation between rainfall and recharge was found when a higher percentage of annual rainfall becomes recharge (Fig. 6). The general pattern for all combinations of soil and vegetation was a reduction in $R / P$ with a reduction in annual mean rainfall. As expected, the percentage of the annual rainfall that becomes recharge reduces under soils with lower permeability and land cover from annual to perennial to trees (Fig. 7). However, this general pattern is also influenced by the climate type. Under annual vegetation $R / P$ 


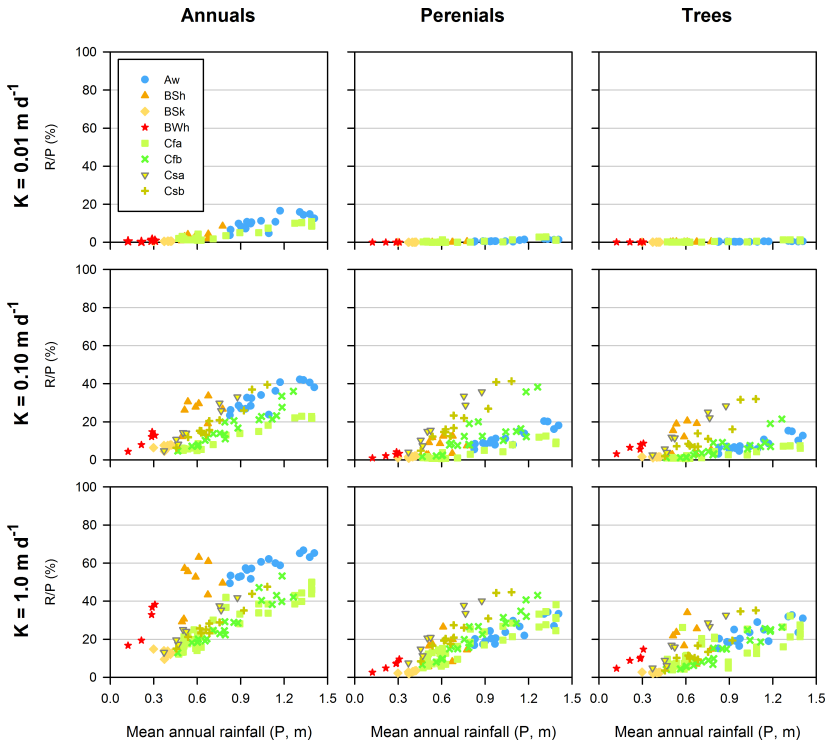

Fig. 7. Scatter plots of mean annual rainfall $(P)$ and percent $P$ which becomes mean annual recharge $(R / P)$ for all modelled locations within considered climate types, under soil with selected hydraulic conductivities and vegetation types.

is greater in the tropics (Aw) and arid climate type (BSh), neighbouring with Aw climate zone. However, under perennial vegetation and trees the highest percentage of the annual rainfall that becomes recharge is associated with the climate types where winter rainfall dominates.

Sensitivity of recharge to changes in rainfall, defined as recharge elasticity $\varepsilon_{R}$, increases under conditions which cause overall less recharge. This includes low rainfall, low soil permeability and under perennial and tree land cover. However for $75 \%$ of all combinations of soil, vegetation and climate types $\varepsilon_{R}$ vary between 2 and 4 , indicating a $20 \%$ to $40 \%$ change in recharge for a $10 \%$ change in annual rainfall (Fig. 8).

The exception to this pattern is related to the cases where recharge was estimated under soil with particularly low hydraulic conductivity $\left(K=0.01 \mathrm{~m} \mathrm{~d}^{-1}\right)$ and perennial vegetation or trees as a land cover. In such conditions, the overall recharge is low, and only significant changes in rainfall can lead to changes in recharge.

\subsection{Rainfall seasonality}

The effect of the rainfall seasonality on recharge rates is illustrated in Fig. 9. It shows the relationship between annual rainfall and annual modelled recharge for all locations which fall within the temperate climate with winterdominated rainfall $(\mathrm{Cs})$ and within the tropical climate with summer-dominated rainfall (Aw) for perennial vegetation and soil with $K$ of $1 \mathrm{md}^{-1}$. These two zones are characterised by the largest (Cs) and smallest (Aw) proportion of the winter rainfall, hence providing the greatest contrast in

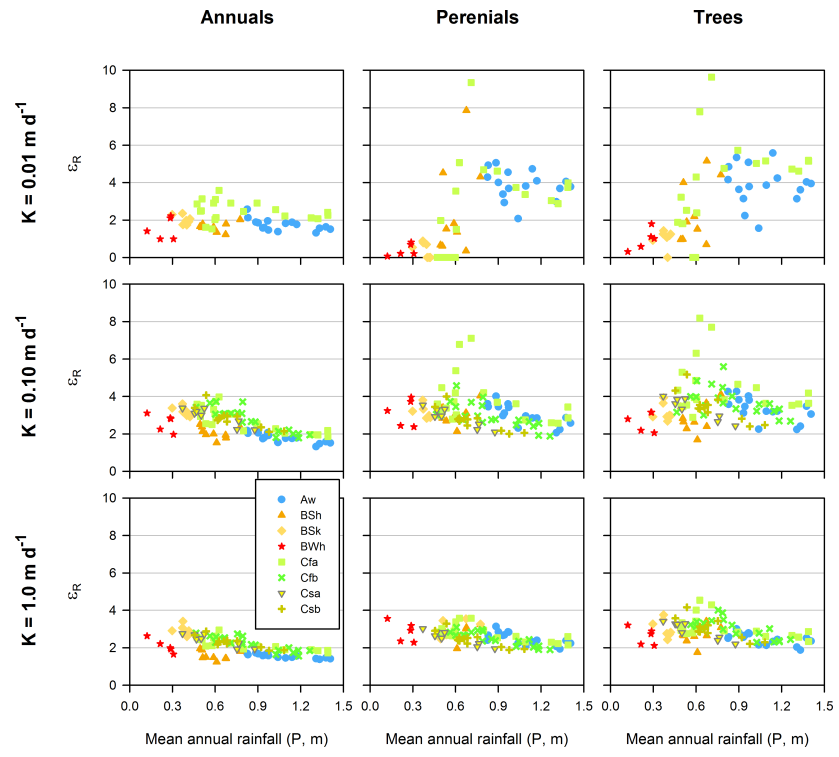

Fig. 8. Scatter plots of mean annual rainfall $(P)$ and recharge elasticity $\left(e_{R}\right)$ for all modelled locations within considered climate types, under soil with selected hydraulic conductivities and vegetation types.
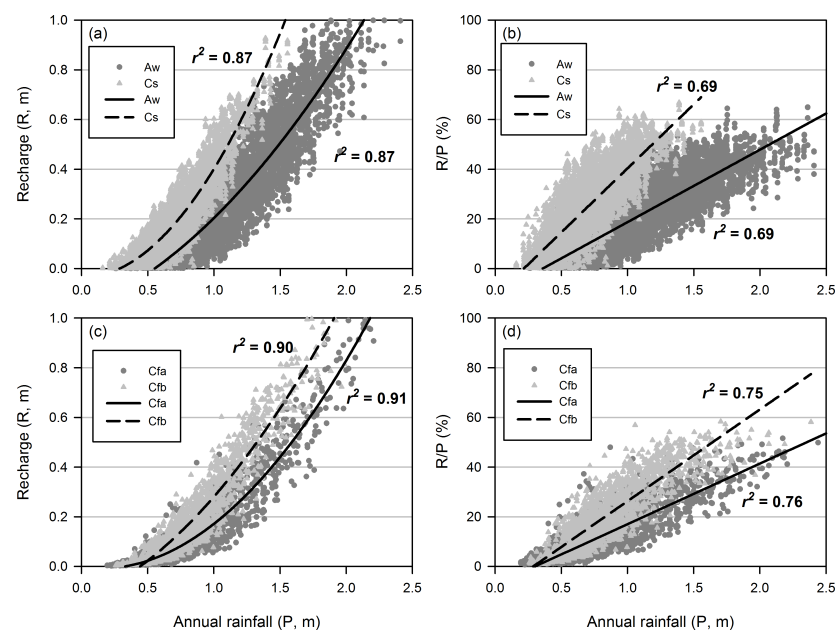

Fig. 9. Relationship between annual recharge $(R)$ and rainfall $(P)$ $(\mathbf{a}, \mathbf{c})$ and between $R / P$ and annual rainfall $(\mathbf{b}, \mathbf{d})$ for perennial vegetation and soil with $K \sim 1 \mathrm{md}^{-1}$; (a) and (b) summer-dominated rainfall (Aw - tropical savannah) and winter-dominated rainfall (Cs - temperate climate with dry summer); (c) and (d) temperate climate without dry summer ( $\mathrm{Cfa}$ - hot summer; $\mathrm{Cfb}$ - warm summer).

rainfall seasonality. On average the estimated recharge is greater under Cs climate type for similar values of annual rainfalls. Similar results were found for trees, as the land cover, and for $K=0.1 \mathrm{~m} \mathrm{~d}^{-1}$ (and heavy soils are not present in Cs zone).

For $\mathrm{Cf}$ climate types, the recharge is greater for $\mathrm{Cfb}$ than for Cfa where under overall equi-seasonal conditions the proportion of winter rainfall is greater. This relationship may 


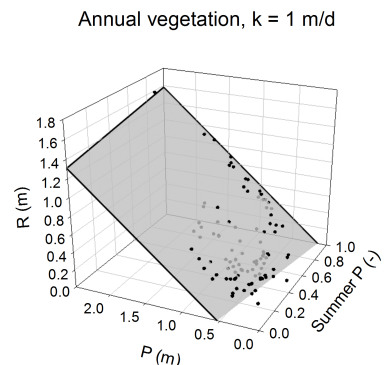

Annual vegetation, $\mathrm{k}=0.01 \mathrm{~m} / \mathrm{d}$

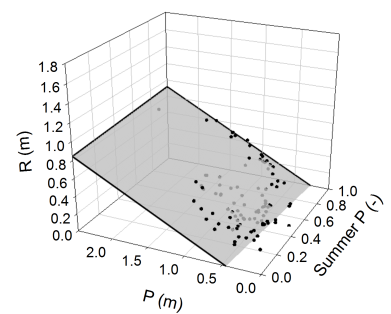

Perennial vegetation, $\mathrm{k}=1 \mathrm{~m} / \mathrm{d}$

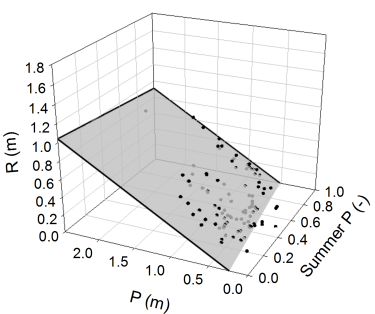

Perennial vegetation, $\mathrm{k}=0.01 \mathrm{~m} / \mathrm{d}$

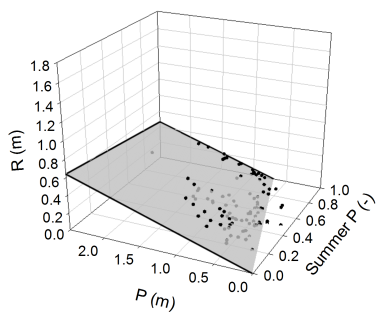

Tree vegetation, $\mathrm{k}=1 \mathrm{~m} / \mathrm{d}$

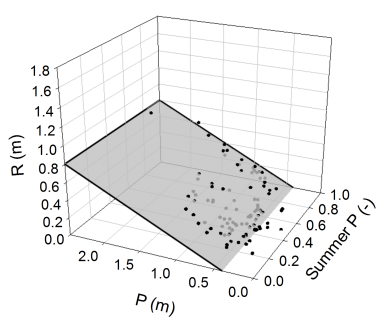

Tree vegetation, $k=0.01 \mathrm{~m} / \mathrm{d}$

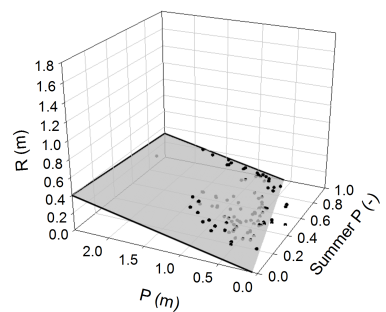

Fig. 10. Relationship between mean annual recharge $(R)$, mean annual rainfall $(P)$ and proportion of annual precipitation which falls during summer (Summer $P$ ).

also be influenced by overall cooler conditions under $\mathrm{Cfb}$ climate (Table 1).

The effect of rainfall seasonality of the estimated recharge is also evident in Fig. 10, showing the mean annual recharge values under two soil types, three land cover types and all climate types as a function of the annual rainfall and the proportion of annual rainfall which falls during summer. For perennial vegetation and trees as a land cover, the annual recharge values reduce, when the proportion of summer rainfall increases. However under annual vegetation, the trend is reversed: the annual recharge values increase along with an increase in the proportion of summer rainfall.

Figure 9 also shows that the relationship between recharge and rainfall is not linear; the percentage of annual rainfall that becomes recharge increases during the years with the high annual rainfall. This is due to higher rainfall intensity or duration of wet periods during the wetter years, which is explored further in the following section.

\subsection{Rainfall intensity}

Though there exists an overall high correlation between annual rainfall and recharge, the correlation between recharge and the sum of high intensity rainfall on an annual basis is stronger. Figure 11 shows relationship between $r_{P}^{2}$ and $r_{P_{\mathrm{i}}}^{2}$, where $r_{P}^{2}$ is the coefficient of correlation between recharge and total annual rainfall $(P)$; and $r_{P_{\mathrm{i}}}^{2}$ is the coefficient of correlation between recharge and the annual aggregation of higher intensity rainfall $\left(P_{\mathrm{i}}\right)$. Several different approaches to rainfall intensity assessment were used, including the threshold value ( $5 \mathrm{~mm}, 10 \mathrm{~mm}, 20 \mathrm{~mm}, 40 \mathrm{~mm}, 60 \mathrm{~mm}$ ) (Fig. 11a), rainfall bands (0-20 mm, 20-40 mm, 40-60 mm) (Fig. 11b), a moving-average approach (Fig. 11d) and percentile of the rainfall events (Fig. 11c). When the points on Fig. 11 fall above 1:1 line, this indicates that $r_{P_{\mathrm{i}}}^{2}$ is greater than $r_{P}^{2}$ and that the recharge shows a greater dependency on the annual aggregation of higher intensity rainfall $\left(P_{\mathrm{i}}\right)$ than total annual rainfall $(P)$.

The highest overall correlation was found to be between annual recharge and the annual aggregation of rainfall using a moving average daily rainfall approach. The latter accounts for the high intensity rainfall events and the prolonged periods of smaller rainfall events simultaneously. It was found that $r_{P_{\mathrm{i}}}^{2}$ for 99 percentile daily rainfalls on annual basis is lower than $r_{P}^{2}$ for the majority of cases with exceptions identified for arid climate types as well as for the conditions with highly permeable soils and tree land cover in Csa and Cfb. Coefficients of correlation $r_{P}^{2}$ and $r_{P_{95}}^{2}$ are more comparable, but application of 99 percentile daily rainfalls on annual basis does not lead to a better predictability of the recharge. When the rainfall intensity thresholds are considered, the daily rainfall greater than $20 \mathrm{~mm}$ aggregated on an annual basis provides a better correlation with annual recharge than total annual rainfall under some conditions, such as for Aw and BSk climate type for under perennial and trees (Fig. 12b).

When the coefficient of correlation between annual rainfall and recharge is particularly high $\left(r_{P}^{2}>0.95\right)$ or low $\left(r_{P}^{2}<0.3\right)$, there is less improvement in correlation between recharge and the annual aggregation of rainfall with higher intensity compared to correlation between recharge and annual total rainfall. At the high $r_{P}^{2}$-values the annual rainfall is overall characterised by higher intensity, while at the lower 

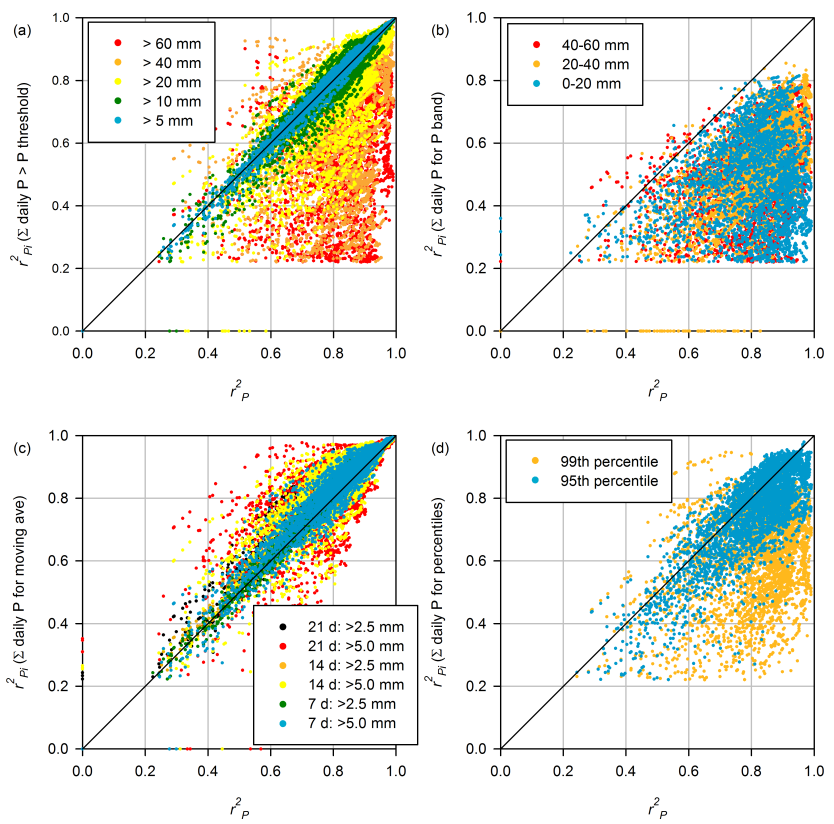

Fig. 11. Comparison of the correlation coefficients $\left(r^{2}\right)$ for the recharge and rainfall relationship: (x-axis) $r_{P}^{2}$ for correlation between annual recharge and total annual rainfall and (y-axis) $r_{P_{\mathrm{i}}}^{2}$ for correlation between annual recharge and (a) sum of the daily rainfall $(P)$ above the identified thresholds; (b) sum of the daily $P$ within the identified bands; (c) sum of the daily $P$ as moving average with identified intervals and daily thresholds; and (d) sum of 95th and 99th percentile daily $P$.

$r_{P}^{2}$ rainfall is likely to be of lower intensity or other than rainfall climate variables play a more important role in recharge estimation.

Under soils with lowest hydraulic conductivity $(K=$ $0.01 \mathrm{~m} \mathrm{~d}^{-1}$ ), the effect of high rainfall intensity on recharge estimation diminishes and $r_{P}^{2}$ and $r_{P_{\mathrm{i}}}^{2}$ are largely similar for all climate types and vegetation covers. For other soil types the least difference between $r_{P}^{2}$ and $r_{P_{\mathrm{i}}}^{2}$ (on average $<5 \%$ ) is under annual vegetation (with exception of Csa climate zone), and also under tropical Aw and arid BSk climate types (Fig. 12a, b). The latter represent the extremes in rainfall intensity across the continent with the highest intensity being typical for the tropic Aw climate type (most daily rainfall is of high intensity), and the lowest - for the arid BSk climate type (most daily rainfall is of low intensity) (Fig. 13a). This also reflects a general trend in reduction of rainfall intensity from the north to the south of the country (Fig. 13b).

\section{Discussion}

\subsection{Climate controls on recharge}

Climatic controls on recharge have not been explicitly addressed in the literature on recharge estimation. This is due
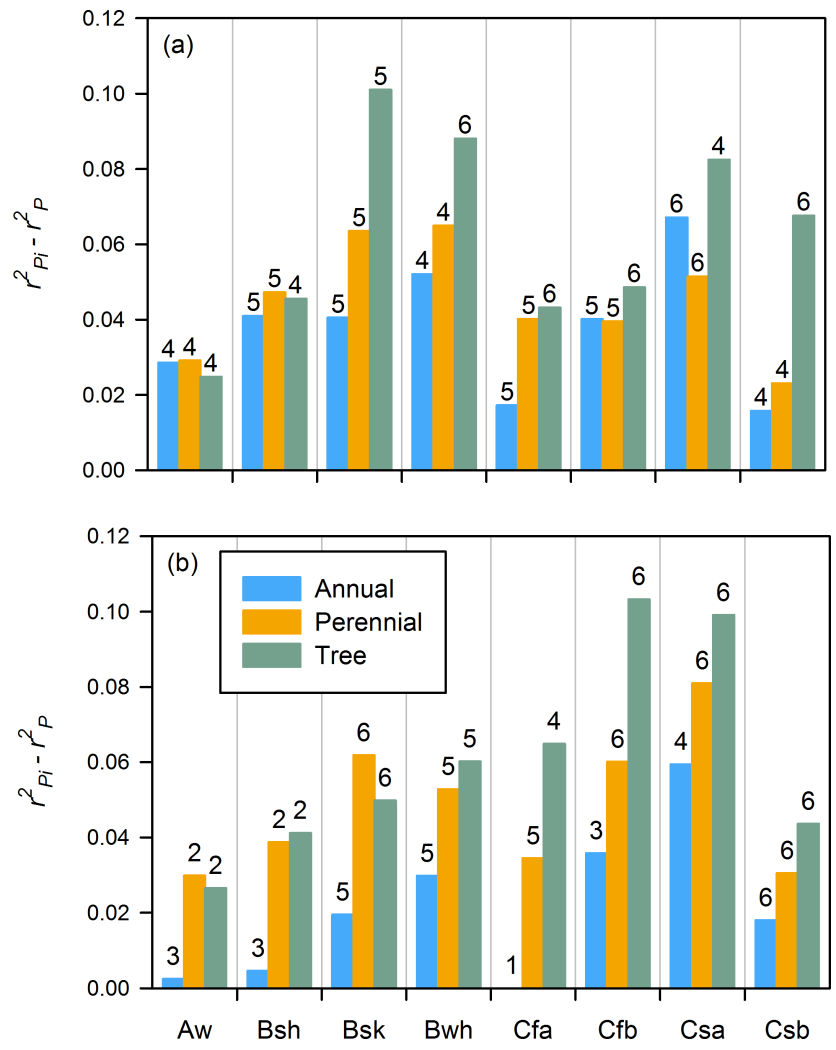

Fig. 12. Differences between $r_{P_{\mathrm{i}}}^{2}$ and $r_{P}^{2}$ for all climate types, vegetation types and two soil types: (a) $K=0.1 \mathrm{md}^{-1}$ and (b) $K=1.0 \mathrm{~m} \mathrm{~d}^{-1}$. The data labels indicate the method of annual rainfall aggregation resulting in a highest differences between $r_{P}^{2}$ and $r_{P_{\mathrm{i}}}^{2}: 1=$ underline all rainfall events, $2=$ a daily rainfall threshold greater than $20 \mathrm{~mm}$, and 3 to 6 all above a rainfall threshold using a moving average, where $3=7$-day window and a threshold of $2.5 \mathrm{~mm} \mathrm{~d}^{-1}, 4=14$-day window and a threshold of $5 \mathrm{~mm} \mathrm{~d}^{-1}$, $5=21$-day window and a threshold of $2.5 \mathrm{~mm} \mathrm{~d}^{-1}$, and $6=21$-day window and a threshold of $5 \mathrm{~mm} \mathrm{~d}^{-1}$.

to the limitation of the available recharge data as well as its dependency on the techniques used for recharge estimation (Crosbie et al., 2010a; Petheram et al., 2002).

It appears that there are certain trends in the relationship between recharge and climate characteristics, and some of these trends are equally relevant across all climate types, but others are more specific for the individual conditions.

In agreement with other published data (Petheram et al., 2002), total annual rainfall was found to be the main factor influencing diffuse recharge across all considered climate types. In general, a reduction in rainfall tends to weaken the correlation between rainfall and recharge as well as reduces the rainfall's importance in recharge estimation. Under low rainfall, the importance of other climate parameters on recharge rises. Among them, VPD and solar radiation appear to be the dominant factors, while annual mean temperature has the lowest importance in recharge estimation within individual climate types. 

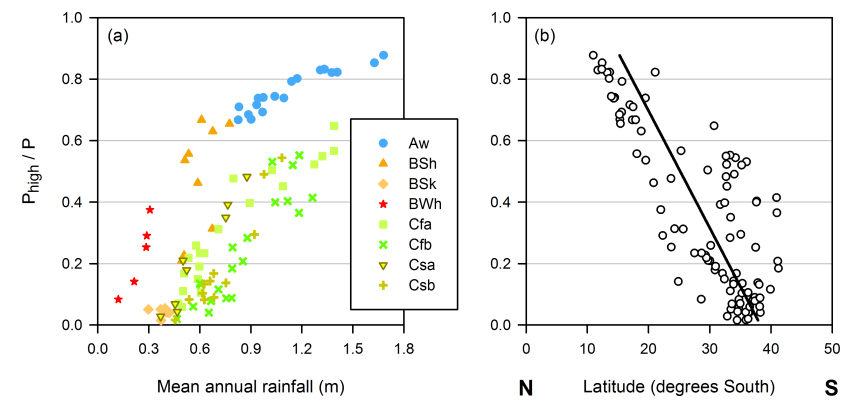

Fig. 13. (a) The proportion of high intensity rainfall $\left(P_{\text {high }}\right)$ in mean annual rainfall $(P)$ for all modelled locations and $(\mathbf{b})$ reduction in this ratio with increasing latitude (north to south of the continent).

An increase in rainfall intensity leads to an increase in (i) recharge, (ii) a proportion of rainfall that becomes recharge, (iii) the relative importance of rainfall, and a reduction in the relative importance of other climate parameters in recharge estimation. Reduction in annual rainfall commonly coincides with a reduction in rainfall intensity, which has a considerable impact on recharge. This is true for both individual modelling locations and climate types at the continental scale.

However, there are some exceptions to this trend which are related to rainfall seasonality and cooler climate types. For the climate types with summer-dominated rainfall (e.g. Aw), the main recharge season is coincidental with higher vegetation water demand and as such leads to a greater influence of VPD, solar radiation and temperature on modelled recharge. As a result, the proportion of rainfall that becomes recharge is generally lower under summer-dominated rainfall for areas under perennials and tree type vegetation. In the climate types with winter-dominated rainfall (such as Cs), the rainfall period coincides with low water demand and vegetation growth, and as a result $R / P$ under perennial vegetation and trees is higher within this climate type compared to Aw climate type. However this trend is not observed under annual vegetation, where $R / P$ in Aw is still greater, which is likely to be related to high rainfall intensity under this climate type.

Under the cooler climates (such as $\mathrm{Cfb}$ ), vegetation growth and water use are sensitive to the changes in annual minimal temperatures and as such this is the only climate type where relative importance of temperature was higher than relative importance of vapour pressure deficit and solar radiation.

Changes in recharge are largely proportional to changes in rainfall but are greater by 2 - to 4 -fold. The recharge elasticity also increases when land cover includes perennial vegetation and trees. However depending on the climate type, the sensitivity of the recharge to changes in rainfall may vary. Relative changes in recharge $\left(\varepsilon_{R}\right)$ are greater under the conditions which generally cause a reduction in recharge, and hence the changes in rainfall may have a greater impact on recharge in climates with lower rainfall (e.g. BSh, BSk or BWh) and in the regions with higher proportion of rainfall during the summer season (e.g. BSh, Cf).
The increase in $\sum \mathrm{RI}^{\mathrm{SR}, \mathrm{VDP}, T}$ in the climate zones with rainfall less than $700 \mathrm{~mm}$ indicates the importance of vegetation in controlling recharge, as these climate variables influence the water use by vegetation.

\subsection{Implications for groundwater resources management}

Understanding of the relationship between recharge and climatic conditions, in addition to soil type and land cover type, has a regional application to management of groundwater resources. Groundwater management in Australia is largely characterised by a focus on the establishment of groundwater extraction limits for groundwater management units (GMUs) based on sustainable yield estimates for defined groundwater systems. Such estimates are largely based on an assessment of the proportion of renewable groundwater resources which can be abstracted for consumptive use. Where groundwater models are not available, and that is in the vast majority of cases, sustainable yield assessment is commonly based on expert estimation of renewable groundwater resources, defined as a percentage of mean annual rainfall. A constant proportion is commonly set for an aquifer regardless of interannual variation in rainfall (DEWHA, 2009). Observations and modelling, however, have shown that this method has a number of shortcomings. In particular, this analysis has revealed a non-linearity in the modelled recharge to rainfall ratio $(R / P)$ for any given location due to variability in rainfall intensity, or the number of consecutive rain days. Furthermore inter-annual rainfall variability is magnified 2- to 4 times in modelled recharge variability. The results of the current analysis indicate that assuming a constant $R / P$ will lead to an overestimation of renewable groundwater resources for lower annual rainfall periods and their underestimation for higher annual rainfall periods. This in turn indicates that, for an adequate water resources assessment, there is a need to account for historical variability of climatic conditions and their effect on renewable groundwater resources.

The analysis was undertaken for eight major climate types, which collectively occupy more than $97 \%$ of the continent. The relationship between groundwater recharge and climate parameters within the remaining seven climate types in Australia is likely to be similar to those in the surrounding major climate zones.

\subsection{Implications for climate change studies}

Under changing climate, caused by global warming, it is likely to expect that climate zones may shift with a consequent effect on renewable groundwater resources.

High relative importance of rainfall indicates that the changes in rainfall may have a greater impact particularly if climate change leads to changes in rainfall intensity and seasonality. A shift in rainfall seasonality may cause a reduction in annual recharge in the climate types dominated by 
winter rainfall, as has been observed in the south-west of the continent (Charles et al., 2010), or an increase in recharge in the climate types dominated by summer rainfall. Projected changes in rainfall seasonality under a future climate have been shown to produce recharge projections in accordance with that described above (Vivoni et al., 2009). The elasticity of the rainfall-recharge relationship and the non-linear nature of the annual $R / P$ relationship are mirrored in the results of climate change impact studies (Barron et al., 2011; Crosbie et al. 2010b, 2012a). These observations demonstrate that understanding the climatic controls on recharge under the historical climate may assist in the analysis of recharge projections under a future climate.

Some researchers have adopted the concept of potential changes in climate type for analysis of the climate change impact on groundwater recharge (Leterme et al., 2012). Within this approach the actual meteorological data from instrumental analogue stations are used for the future climate projection in the areas where the climate type shift is likely to introduce the climate type currently occurring within the region of the analogue stations. The outcome of this analysis may be useful for such applications, indicating that the relationship between recharge and climate parameters may be quite similar in the neighbouring climate zones.

\section{Conclusions}

The results reported here allow certain trends in the control of climate characteristics on diffuse groundwater recharge across Australia to be defined:

- Annual rainfall is a major factor influencing recharge. However, for the majority of the considered climate types, recharge shows a greater dependency on the rainfall parameters reflecting higher rainfall intensity $\left(r_{P}^{2}<r_{P_{\mathrm{i}}}^{2}\right)$. The exceptions are related to the tropical Aw climate type where the majority of rainfall events are of high intensity (and $r_{P}^{2}$ is particularly high) and arid BSk where the majority of rainfall events are of low intensity (and $r_{P}^{2}$ is particularly low).

- Annual recharge is more sensitive to daily rainfall intensity in regions with winter-dominated rainfall, where it is also less sensitive to absolute changes in annual rainfall.

- In regions with winter-dominated rainfall, annual recharge under the same annual rainfall and soil conditions is less than in regions with summer-dominated rainfall for perennial vegetation and trees as land cover. However this trend is not observed under annual vegetation.

- Relative importance of annual rainfall in recharge estimation reduces under lower rainfall conditions, and along with that there is an increase in the relative importance of other climate parameters in recharge estimation (temperature, solar radiation and vapour pressure deficit). The effect of climate parameters other than rainfall on recharge is greater under climate types with summer-dominated rainfall and under cooler climate types.

- An increase in rainfall intensity leads to an increase in recharge, a higher proportion of rainfall that becomes recharge, an increase in the relative importance of rainfall, and a reduction in the relative importance of other climate parameters in recharge estimation.

- There is a non-linear relationship between recharge and rainfall, which is likely due to the effect of rainfall intensity or duration of consecutive days with rainfall. Therefore, the proportion of recharge in annual rainfall $(R / P)$ is not likely to be a constant - even under the same land cover and soil type.

- Annual changes in recharge are largely proportional to annual changes in rainfall but are not equal. It has been demonstrated that changes in annual rainfall lead to 2to 4 -fold greater changes in recharge.

Acknowledgements. The authors would like to acknowledge the National Water Commission of Australia for providing funding for the Climate Change Impacts on Groundwater Resources project under the National Groundwater Action Plan.

Edited by: R. P. Bartholomeus

\section{References}

Allen, D. M., Mackie, D. C., and Wei, M.: Groundwater and climate change: a sensitivity analysis for the Grand Forks aquifer, southern British Columbia, Canada, Hydrogeol. J., 12, 270-290, 2004.

Barron, O. V., Crosbie, R. S., Charles, S. P., Dawes, W. R., Ali, R., Evans, W. R., Cresswell, R. G., Pollock, D., Hodgson, G., Currie, D., Mpelasoka, F. S., Pickett, T., Aryal, S., Donn, M., and Wurcker, B.: Climate change impact on groundwater resources in Australia, Waterlines Report No. 67, National Water Commission, Canberra, 2011.

BoM: Australian Climate Influences, available at: www.bom.gov.au/watl/about-weather-and-climate/ australian-climate-influences.shtml (last access: 22 November 2012), Bureau of Meteorology, 2011 a.

BoM: Australian climate variability and change - Trend maps, available at: http://www.bom.gov.au/cgi-bin/climate/change/ trendmaps.cgi (last access: 22 November 2012), Bureau of Meteorology, 2011b.

Charles, S. P., Silberstein, R., Teng, J., Fu, G., Hodgson, G., Gabrovsek, C., Crute, J., Chiew, F. H. S., Smith, I. N., Kirono, D. G. C., Bathols, J. M., Li, L. T., Yang, A., Donohue, R. J., 
Marvanek, S. P., McVicar, T. R., Van Niel, T. G., and Cai, W.: Climate analyses for south-west Western Australia. A report to the Australian Government from the CSIRO South-West Western Australia Sustainable Yields Project, CSIRO, 2010.

Chiew, F. H. S.: Estimation of rainfall elasticity of streamflow in Australia, Hydrolog. Sci. J., 51, 613-625, 2006.

Crosbie, R. S., Wilson, B., Hughes, J. D., McCulloch, C., and King, W. M.: A comparison of the water use of tree belts and pasture in recharge and discharge zones in a saline catchment in the Central West of NSW, Australia, Agr. Water Manage., 95, 211-223, 2008.

Crosbie, R. S., Jolly, I. D., Leaney, F. W., and Petheram, C.: Can the dataset of field based recharge estimates in Australia be used to predict recharge in data-poor areas?, Hydrol. Earth Syst. Sci., 14, 2023-2038, doi:10.5194/hess-14-2023-2010, 2010a.

Crosbie, R. S., McCallum, J. L., Walker, G. R., and Chiew, F. H. S.: Modelling the climate change impact on groundwater recharge in the Murray-Darling Basin, Hydrogeol. J., 18, 1639-1656, 2010 b.

Crosbie, R. S., Dawes, W. R., Charles, S. P., Mpelasoka, F. S., Aryal, S., Barron, O., and Summerell, G. K.: Differences in future recharge estimates due to GCMs, downscaling methods and hydrological models, Geophys. Res. Lett., 38, L11406, doi:10.1029/2011g1047657, 2011a.

Crosbie, R., Pickett, T., Mpelasoka, F., Hodgson, G., Charles, S., and Barron O. V.: Diffuse recharge across Australia under a 2050 climate: Modelling results, CSIRO: Water for a Healthy Country National Research Flagship, 2011b.

Crosbie, R. S., McCallum, J. L., Walker, G. R., and Chiew, F. H. S.: Episodic recharge and climate change in the Murray-Darling Basin, Australia, Hydrogeol J., 20, 245-261, doi:10.1007/s10040-011-0804-4, 2012a.

Crosbie, R. S., Pickett, T., Mpelasoka, F. S., Hodgson, G., Charles, S. P., and Barron, O. V.: An assessment of the climate change impacts on groundwater recharge at a continental scale using a probabilistic approach with an ensemble of GCMs, Climatic Change, doi:10.1007/s10584-012-0558-6, Print ISSN: 01650009, 2012 b.

Crosbie, R. S., Pollock, D. W., Mpelasoka, F. S., Barron, O. V., Charles, S. P., and Donn, M. J.: Changes in Köppen-Geiger climate types under a future climate for Australia: hydrological implications, Hydrol. Earth Syst. Sci., 16, 3341-3349, doi:10.5194/hess-16-3341-2012, 2012c.

CSIRO: Water availability in the Murray-Darling Basin. A report to the Australian Government from the CSIRO Murray-Darling Basin Sustainable Yields Project. Water for a Healthy Country National Research Flagship, Australia, CSIRO, available at: http://www.csiro.au/files/files/po0n.pdf (last access: 22 November 2012), 2008.

CSIRO: Water availability for Tasmania: CSIRO Tasmania Sustainable Yields Project. Water for a Healthy Country National Research Flagship, Canberra, CSIRO, 2009a.

CSIRO: Water in northern Australia: Summary of reports to the Australian Government from the CSIRO Northern Australia Sustainable Yields Project. Water for a Healthy Country Flagship National Research Flagship, Canberra, CSIRO, 2009b.

CSIRO: Water yields and demands in south-west Western Australia. A report to the Australian Government from the CSIRO SouthWest Western Australia Sustainable Yields Project. CSIRO Water for a Healthy Country Flagship, Australia, CSIRO, available at:
http://www.csiro.au/partnerships/SWSY, 306 pp., 2009c.

Dawes, W. R., Gilfedder, M., Stauffacher, M., Coram, J., Hajkowicz, S., Walker, G. R., and Young, M.: Assessing the viability of recharge reduction for dryland salinity control: Wanilla, Eyre Peninsula, Aust. J. Soil Res., 40, 1407-1424, 2002.

Dawes, W. R., Zhang, L., and Dyce, P.: WAVES v3.5 User Manual. CSIRO Land and Water, Canberra, 2004.

DEWHA: Australian Natural Resources Atlas, W. H. Department of Environment, Editor, Australian Natural Resources Atlas, DEWHA, available at: http://www.anra.gov.au (last access: September 2010), 2009.

DEWHA: Securing our Water Future, edited by: DEWHA Australian Government Department of the Environment, Water, Heritage and the Arts, available at: http://www.environment.gov. au/water/publications/action/pubs/securing-water-future.pdf (last access: 22 November 2012), 2010.

Döll, P.: Vulnerability to the impact of climate change on renewable groundwater resources: a global-scale assessment, Environ. Res. Lett., 4, 35006-35006, 2009.

Eckhardt, K. and Ulbrich, U.: Potential impacts of climate change on groundwater recharge and streamflow in a central European low mountain range, J. Hydrol., 236, 244-252, 2003.

Gromping, U.: Relative importance for linear regression in R: The package relaimpo, J. Stat. Softw., 17, 27 pp., 2006.

Håkanson, L. and Peters, R. H.: Predictive limnology - Methods for predictive modelling, SPB Academic Publishing: Amsterdam, 1995.

IPCC: Climate Change 2007: The Physical Science Basis. Contribution of Working Group 1 to the Fourth Assessment Report of the Intergovernmental Panel on Climate Change, Cambridge University Press, Cambridge UK, 2007.

Jeffrey, S. J., Carter, J. O., Moodie, K. B., and Beswick, A. R.: Using spatial interpolation to construct a comprehensive archive of Australian climate data, Environ. Modell. Softw., 16, 309-330, 2001.

Johnston, R. M., Barry, S. J., Bleys, E., Bui, E. N., Moran, C. J., Simon, D. A. P., Carlile, P., McKenzie, N. J., Henderson, B. L., Chapman, G., Imhoff, M., Maschmedt, D., Howe, D., Grose, C., Schoknecht, N., Powell, B., and Grundy, M.: ASRIS: the database, Aust. J. Soil. Res., 41, 1021-1036, 2003.

Jyrkama, M. I. and Sykes, J. F.: The impact of climate change on spatially varying groundwater recharge in the grand river watershed (Ontario), J. Hydrol., 338, 237-250, 2007.

Kingston, D. G. and Taylor, R. G.: Sources of uncertainty in climate change impacts on river discharge and groundwater in a headwater catchment of the Upper Nile Basin, Uganda, Hydrol. Earth Syst. Sci., 14, 1297-1308, doi:10.5194/hess-14-12972010, 2010.

Leterme, B., Mallants, D., and Jacques, D.: Estimation of future groundwater recharge using climatic analogues and Hydrus-1D, Hydrol. Earth Syst. Sci. Discuss., 9, 1389-1410, doi:10.5194/hessd-9-1389-2012, 2012.

Lindeman, R. H., Merenda, P. F., and Gold, R. Z.: Introduction to Bivariate and Multivariate Analysis, Scott, Foresman, Glenview, IL, 1980.

McCallum, J. L., Crosbie, R. S., Walker, G. R., and Dawes, W. R.: Impacts of climate change on groundwater: A sensitivity analysis of recharge, Hydrogeol. J., 18, 1625-1638, 2010. 
Monteith, J. L.: Climatological measurements, Photosynth., Praha, 129-132, 1967.

Ng, G. H. C., McLaughlin, D., Entekhabi, D., and Scanlon, B. R.: Probabilistic analysis of the effects of climate change on groundwater recharge, Water Resour. Res., 46, 7502-7502, 2010.

Okkonen, J., Jyrkama, M., and Klove, B.: A conceptual approach for assessing the impact of climate change on groundwater and related surface waters in cold regions (Finland), Hydrogeol. J., 18, 429-439, 2010.

Owor, M., Taylor, R. G., Tindimugaya, C., and Mwesigwa, D.: Rainfall intensity and groundwater recharge: empirical evidence from the Upper Nile Basin, Environ. Res. Lett., 4, 035009, doi:10.1088/1748-9326/4/3/035009, 2009.

Peel, M. C., Finlayson, B. L., and McMahon, T. A.: Updated world map of the Köppen-Geiger climate classification, Hydrol. Earth Syst. Sci., 11, 1633-1644, doi:10.5194/hess-11-16332007, 2007.

Penman, H. L.: Evaporation from forests: a comparison of theory and observation, International symposium on forest hydrology, Permagon Press, Oxford, England, 373-380, 1967.

Petheram, C., Walker, G., Grayson, R., Thierfelder, T., and Zhang, L.: Towards a framework for predicting impacts of land-use on recharge: 1. A review of recharge studies in Australia, Aust. J. Soil Res., 40, 397-417, 2002.

Rosenberg, N. J., Epstein, D. J., Wang, D., Vail, L., Srinivasan, R., and Arnold, J. G.: Possible Impacts of Global Warming on the Hydrology of the Ogallala Aquifer Region, Climatic Change, 42, 677-692, 1999.

Salama, R., Hatton, T., and Dawes, W.: Predicting land use impacts on regional scale groundwater recharge and discharge, J. Environ. Qual., 28, 446-460, 1999.

Scanlon, B. R., Christman, M., Reedy, R. C., Porro, I., Simunek, J., and Flerchinger, G. N.: Intercode comparisons for simulating water balance of surficial sediments in semiarid regions, Water Resour. Res., 38, 1323-1323, 2002.

Schaake, J. C.: From climate to flow. In: Climate Change and U.S. Water Resources, edited by: Waggoner P. E., John Wiley, New York, 177-206, 1990.

Serrat-Capdevila, A., Valdés, J. B., Pérez, J. G., Baird, K., Mata, L. J., and Maddock, T.: Modeling climate change impacts - and uncertainty - on the hydrology of a riparian system: The San Pedro Basin (Arizona/Sonora), J. Hydrol., 347, 48-66, 2007.
Slavich, P. G., Walker, G. R., Jolly, I. D., Hatton, T. J., and Dawes, W. R.: Dynamics of Eucalyptus largiflorens growth and water use in response to modified watertable and flooding regimes on a saline floodplain, Agr. Water Manage., 39, 245-264, 1999.

Vivoni, E. R., Aragón, C. A., Malczynski, L., and Tidwell, V. C.: Semiarid watershed response in central New Mexico and its sensitivity to climate variability and change, Hydrol. Earth Syst. Sci., 13, 715-733, doi:10.5194/hess-13-715-2009, 2009.

Wang, H. X., Zhang, L., Dawes, W. R., and Liu, C. M.: Improving water use efficiency of irrigated crops in the North China Plain measurements and modelling, Agr. Water Manage., 48, 151-167, 2001.

Wu, H., Rykiel, E. J., Hatton, T., and Walker, J.: An integrated rate methodology (IRM) for multi-factor growth rate modelling, Ecol. Model., 73, 97-116, 1994.

Xu, C., Martin, M., Silberstein, R., and Smetten, K.: Identifying souirces of uncertainty in groundwater recharge estimates using the biophysical model WAVES, Water Down Under, Adelaide, Australia, 2008.

Yang, Y. H., Watanabe, M., Wang, Z. P., Sakura, Y., and Tang, C. Y.: Prediction of changes in soil moisture associated with climatic changes and their implications for vegetation changes: WAVES model simulation on Taihang Mountain, China, Climatic Change, 57, 163-183, 2003.

Zhang, L. and Dawes, W.: WAVES - An integrated energy and water balance model, CSIRO Land and Water, CSIRO, 1998.

Zhang, L., Dawes, W. R., and Hatton, T. J.: Modelling hydrologic processes using a biophysically based model-application of WAVES to FIFE and HAPEX-MOBILHY, J. Hydrol., 185, 147-169, 1996.

Zhang, L., Dawes, W. R., Hatton, T. J., Hume, I. H., O'Connell, M. G., Mitchell, D. C., Milthorp, P. L. and Yee, M.: Estimating episodic recharge under different crop/pasture rotations in the Mallee region. Part 2. Recharge control by agronomic practices, Agr. Water Manage., 42, 237-249, 1999. 